\title{
Apolipoprotein B gene variants are involved in the determination of blood glucose and lipid levels in patients with non-insulin dependent diabetes mellitus
}

\author{
Belgin Süsleyici Duman ${ }^{1}$, Melek Öztürk*², Selma Yılmazer ${ }^{2}$, Penbe Çağatay ${ }^{3}$ and Hüsrev Hatemi ${ }^{4,5}$ \\ ${ }^{1}$ Kadir Has University, Faculty of Medicine, Medical Biology and Genetics Department, Istanbul, Turkey \\ ${ }^{2}$ Istanbul University, Cerrahpasa Faculty of Medicine, Medical Biology Department, İstanbul, Turkey \\ ${ }^{3}$ Istanbul University, Cerrahpasa Faculty of Medicine, Biostatistics Department, İstanbul, Turkey \\ ${ }^{4}$ Turkish Diabetes Hospital, Dr Celal Oker Street. No. 10 Harbiye, İstanbul, Turkey \\ ${ }^{5}$ Istanbul University, Cerrahpasa Faculty of Medicine, Endocrinology and Metabolism Department, Istanbul, Turkey
}

\begin{abstract}
We have examined the frequency of the EcoRI, XbaI and MspI RFLPs of the apolipoprotein B (apo B) gene in 110 type 2 diabetic patients and 91 healthy control subjects in order to ascertain whether variation in this gene may influence the development of non-insulin dependent diabetes mellitus (type 2 diabetes). Serum lipids including total-cholesterol (T-Chol), triacylglycerol (TAG), apolipoprotein E (apo E), apolipoprotein AI (apo AI), apolipoprotein B and lipoprotein (a) (Lp(a)) were analysed. Genomic DNA was extracted and the apo B polymorphic regions amplified by the polymerase chain reaction. Regions carrying EcoRI, XbaI, and MspI restriction sites present in the apo B gene were amplified and digested separately by the respective enzymes. No significant difference for genotypic frequencies was observed for the EcoRI, XbaI and MspI restriction sites in type 2 diabetic patients as compared to controls. Type 2 diabetic patients and controls with EcoRI $+/+$ and $\mathrm{XbaI}+/+$ genotypes had higher apo E levels. The MspI $+/+$ genotype is more frequent in the patient and control groups with elevated T-Chol. Furthermore, the EcoRI $-/-$, XbaI $-/-$, and MspI $+/+$ genotypes were found to be significantly more frequent in type 2 diabetic patients with higher blood glucose levels. This study identifies the apo B gene polymorphisms in modulating plasma lipid/lipoprotein and glucose levels in patients with type 2 diabetes. Copyright (C) 2005 John Wiley \& Sons, Ltd.
\end{abstract}

KEY WORDS - non-insulin dependent diabetes mellitus; apolipoprotein B; polymorphism

\section{INTRODUCTION}

Type 2 diabetes mellitus is a heterogeneous disorder that develops in response to both genetic and environmental factors. ${ }^{1-5}$ The predisposition to type 2 diabetes is thought to be conferred by a number of different genes that in isolation may have only minor effects, but in combination lead to the characteristic pathophysiological condition. ${ }^{6}$ This genetic susceptibility may be preferentially conferred by an unfa* Correspondence to: Professor Melek Öztürk, İstanbul University,
Cerrahpasa Faculty of Medicine, Medical Biology Department
Cerrahpaşa, İstanbul, Turkey. Tel: 009053244248 34. Fax: 0090 21263200 50. E-mail: ozturkmel@ superonline.com vourable combination of individual polymorphisms in the genes involved, each one controlling part of the pathogenic process. ${ }^{7}$

Apolipoprotein $\mathrm{B}$ is a major protein component of low density lipoprotein (LDL). Apo B plays a central role in lipoprotein metabolism through regulation of total cholesterol (T-Chol) and LDL concentrations in plasma. This regulation is mediated by binding of apo $\mathrm{B}$, present in LDL, to LDL receptors (LDLR) on the cell surface. ${ }^{8}$ Genetic polymorphisms of apo B have been shown to have a significant effect on plasma lipid levels and have been associated with type 2 diabetes in some studies. ${ }^{9,10}$ Diabetic dyslipidemia comprises multiple lipoprotein disorders. The most typical findings are high triacylglycerol (TAG) concentrations, low levels of high density lipoprotein-cholesterol (HDL-Chol) and normal or slightly increased 
LDL-Cholesterol (LDL-Chol). ${ }^{11-13}$ Some degree of lipid alteration persists in type 2 diabetic patients despite improved metabolic control accompanying therapy. ${ }^{12,14}$ The interaction of apo B with LDLR mediates the uptake of LDL from the liver and peripheral cells; hence, apo B plays an important role in cholesterol homeostasis. ${ }^{15}$ Apo $\mathrm{B}$ is the largest monomeric protein sequenced so far, containing 4536 amino acid residues. Its gene has been mapped to the short arm of chromosome 2, with an approximate length of 43 kilobases and 29 exons. ${ }^{16}$ The cloning and sequencing of the apo $\mathrm{B}$ gene has made it possible to study the variations in the apo B gene at the DNA level. Several studies have reported that some restriction fragment length polymorphisms (RFLP) $)^{9,10,17}$ of apo B are associated with type 2 diabetes, or with variations in plasma lipids, while others do not find such an association. ${ }^{18}$ The EcoRI polymorphism of the apo B gene detects a mutation in the coding region (exon 29) G12669A, replacing Glu by Lys in the peptide, the main domain for recognition of the LDL-receptor. ${ }^{19,20} \mathrm{MspI}$ polymorphism in codon 3611 of the mature apo B protein, results in an amino acid change from arginine to glutamine. ${ }^{21}$ On the other hand, the polymorphic region of $\mathrm{XbaI}$ is caused by a base substitution $(\mathrm{A} \rightarrow \mathrm{T})$ in the threonine codon, resulting in a silent mutation. ${ }^{22,23}$ Apo $\mathrm{B}$ gene MspI and XbaI polymorphisms in exon 26 have been associated with variations in lipid levels. ${ }^{24-26}$ Apo B EcoRI RFLP is related to changes in LDL-Chol during low and high cholesterol intake. ${ }^{27}$

Since the contribution of apo B gene polymorphisms to the development of type 2 diabetes differs among populations, the aim of the present study, is to investigate the influence of the EcoRI, XbaI and MspI polymorphisms over lipid parameters and their association with type 2 diabetes by evaluating their frequency distributions in Turkish patients with this condition compared with controls.

\section{MATERIAL AND METHODS}

\section{Subjects}

We have studied 111 unrelated type 2 diabetic patients (48 men and 63 women). These were outpatients from the Turkish Diabetes Hospital (İstanbul, Turkey). The diagnosis was based on the criteria of The Expert Committee on the Diagnosis of Diabetes Mellitus. ${ }^{28}$ The study protocol was approved by the Ethics Committee of the İstanbul University, Cerrahpasa Faculty of Medicine, and informed consent was obtained from each participant. The control group consisted of 94 unrelated healthy individuals ( 31 men and 63 women) not taking medication, who either attended a routine health check at a general practice or were staff of the Cerrahpasa Faculty of Medicine (İstanbul University, Turkey). The hepatic and endocrine functions of the patients were normal and all were relatively well controlled with glycosylated haemoglobin $\left(\mathrm{HbA}_{1 \mathrm{c}}\right) \leq 6-7 \%$ (normal range $\leq 8 \%$ ). Patients with macro- and microangiopathic complications were excluded from this study.

\section{Clinical and biochemical evaluation}

Blood samples were collected after overnight $(>12 \mathrm{~h})$ fasting. Serum was obtained after leaving the blood tubes for $30 \mathrm{~min}$ at room temperature followed by 10 min centrifugation. The body mass index (BMI) was calculated and overweight (obese) was defined as a value $>25 \mathrm{~kg} / \mathrm{m}^{2}{ }^{29}$ The biochemical analysis included determination of fasting plasma glucose, TAG, T-Chol, apo E, apo AI, apo B and Lp(a). Serum TAG and T-Chol levels were measured using standard enzymic methods (Merck, Darmstadt, Germany), automated on an AU5021 analyser (Olympus, Merck). Serum apo E was determined by turbidimetry automated on a Cobas-Mira analyser (Roche, Meylan, France); serum apo AI, apo B and Lp (a) were determined by immunonephelometry on a Behring Nephelometer analyser with Behring reagents (Behringwerke, Marburg, Germany). Sera were analysed without pretreatment and diluted in double-distilled water when lipid or apolipoprotein levels exceeded reference values. Pooled sera were included in each series of measurements for apo E. Between assays coefficient of variation of these methods were 2.14, $4.66,0.95,1.52,2.92,4.34$ and $1.53 \%$ respectively for T-Chol, TAG, glucose, apo E, apo AI, apo B and Lp (a).

\section{Molecular analysis}

Genomic DNA was extracted from leukocytes by a salting out procedure. ${ }^{30}$ The desired segments were amplified by $\mathrm{PCR}^{31}$ using the apo B EcoRI, ${ }^{32} \mathrm{XbaI},{ }^{33}$ and $\mathrm{MspI}^{34}$ protocols with the respective primers (Gibco BRL, Rockville, MD, USA); EC1:5'-CTG AGA GAA GTG TC T TCG AAG- $3^{\prime}$ and EC2:5'CTC GAA AGG AAG TGT AAT CAC- $3^{\prime}$ for EcoRI; XB1:5'- GGA GAC TAT TCA GAA GCT AA- $3^{\prime}$ and XB2:5' - GAA GAG CCT GAA GAC TGA CT- $3^{\prime}$ for XbaI; MS1:5' - CAA TTC AGT CCA GGA GAA GCA- $3^{\prime}$ and MS2:5' - CAG CAA CCG AGA AGG GCA CTC AG- $3^{\prime}$ for MspI. 
The final amplification products were submitted to digestion with the respective restriction enzymes (EcoRI, XbaI and MspI) and visualized on 1.5\% agarose gel. The apo B alleles with the restriction sites present for the enzymes XbaI, MspI, and EcoRI are designated as $\mathrm{X}+, \mathrm{M}+$, and $\mathrm{R}+$ and those alleles lacking the restriction site as $\mathrm{X}-, \mathrm{M}-$, and $\mathrm{R}-$, respectively.

\section{Statistical analysis}

Statistical analyses were conducted using Unistat 5.1 software. Serum TAG and Lp (a) have been logarithmically transformed before the analysis to obtain normal distribution of data. A comparison of variables between two groups or among three groups was performed using an unpaired $t$-test or one-way ANOVA, respectively. Hardy-Weinberg equilibrium for genotype frequencies was estimated by the chi-square test. The variables across the various genotypes and groups for each RFLP were estimated by two-way ANOVA with an interaction term to test the influence of genotypes on the lipid profile. $p$ values less than 0.05 were considered significant.

\section{RESULTS}

Three polymorphisms present in the apo B gene were analysed: EcoRI, XbaI and MspI in 111 type 2 diabetics and 94 control subjects. The BMI and biochemical (T-Chol, TAG, apo E, apo AI, apo B and Lp(a)) characteristics of subjects are shown in Table 1. The frequency distributions of major type 2 diabetes risk factors did not show any significant difference between patient and control groups (Table 2). The genotype frequency distributions for the type 2 diabetic and control groups with respect to EcoRI, XbaI, and MspI polymorphisms were compared. The apo B gene EcoRI, XbaI, and MspI polymorphisms frequen-

Table 1. Demographic data of the non-insulin dependent diabetes mellitus and control groups

\begin{tabular}{lcc}
\hline & Patient $(n=111)$ & Control $(n=94)$ \\
\hline Age $($ years $)$ & $57.99 \pm 9.16$ & $55.46 \pm 11.26$ \\
BMI $\left(\mathrm{kg} \mathrm{m}^{-2}\right)$ & $27.39 \pm 4.34$ & $26.86 \pm 4.15$ \\
Glucose $\left(\mathrm{mmol} \mathrm{l}^{-1}\right)$ & $8.25 \pm 3.62^{\dagger}$ & $3.61 \pm 0.59$ \\
Total cholesterol $\left(\mathrm{mmol} \mathrm{l}^{-1}\right)$ & $4.73 \pm 2.49$ & $5.48 \pm 1.30$ \\
Triacylglycerol $\left(\mathrm{mmol} \mathrm{l}^{-1}\right)$ & $1.99 \pm 1.36$ & $1.75 \pm 0.90$ \\
Apolipoprotein E $\left(\mathrm{mg} \mathrm{l}^{-1}\right)$ & $41.00 \pm 14.52$ & $49.21 \pm 31.18^{*}$ \\
Apolipoprotein AI $\left(\mathrm{g} \mathrm{l}^{-1}\right)$ & $1.42 \pm 0.27$ & $1.41 \pm 0.26$ \\
Apolipoprotein B $\left(\mathrm{g} \mathrm{l}^{-1}\right)$ & $1.15 \pm 0.37$ & $1.11 \pm 0.28$ \\
Lp(a) $\left(\mathrm{g} \mathrm{l}^{-1}\right)$ & $0.14 \pm 0.16$ & $0.18 \pm 0.17$ \\
\hline
\end{tabular}

Values are represented as mean $\pm \mathrm{SD} .{ }^{*} p<0.05,{ }^{\dagger} p<0.001$.
Table 2. Risk factors for non-insulin dependent diabetes mellitus in patients and control subjects

\begin{tabular}{lccc}
\hline & Diabetes $n(\%)$ & Control $n(\%)$ & $p$ \\
\hline Gender & & & \\
$\quad$ Male & $48(43.2)$ & $31(33)$ & NS \\
Female & $63(56.8)$ & $63(67.1)$ & NS \\
Dyslipidemia & $25(22.5)$ & $17(18.7)$ & NS \\
Obesity & $75(67.6)$ & $57(62.6)$ & NS \\
Smokers & $15(18.8)$ & - & - \\
\hline
\end{tabular}

The variables were compared with the $\chi^{2}$ test among groups. NS, not statistically significant.

cies for $+/-,-/-$ and $+/+$ genotypes were respectively $34.2,1.8,64 ; 46.7,43,10.3 ; 37.8,26.1,36$ in subjects with type 2 diabetes, and 36.2, 6.4, 57.4; $41.5,50,8.5 ; 46.8,27.7,25.5$ in the control group. No significant difference was observed in genotype frequencies between the type 2 diabetic and control groups. Hardy-Weinberg equilibrium was tested on the whole study population $(n=205)$. According to Hardy-Weinberg proportion, the analysed genotypes are in equilibrium. Association of the apo B gene EcoRI, XbaI, and MspI polymorphisms with lipid parameters are shown in Table 3, 4 and 5, respectively. The apo E levels were found to be elevated in

Table 3. Effects of ApoB gene EcoRI polymorphism on clinical parameters in non-insulin dependent diabetes mellitus patients and control subjects

\begin{tabular}{|c|c|c|c|c|}
\hline & & \multicolumn{2}{|c|}{ Genotype } & \multirow[b]{2}{*}{ ) } \\
\hline & & $\begin{array}{c}\mathrm{R}+/ \mathrm{R}- \\
\text { Control }(n=34) \\
\text { Patient }(n=38)\end{array}$ & $\begin{array}{c}\mathrm{R}+/ \mathrm{R}+ \\
\text { Control }(n=54) \\
\text { Patient }(n=70)\end{array}$ & \\
\hline BMI $\left(\mathrm{kg} \mathrm{m}^{-2}\right)$ & $\begin{array}{l}\text { Control } \\
\text { Patient }\end{array}$ & $\begin{array}{l}27.39 \pm 3.85 \\
26.96 \pm 4.42\end{array}$ & $\begin{array}{l}26.85 \pm 4.23 \\
27.68 \pm 4.29\end{array}$ & NS \\
\hline $\begin{array}{l}\text { Glucose } \\
\left(\mathrm{mmol}^{-1}\right)\end{array}$ & $\begin{array}{l}\text { Control } \\
\text { Patient }\end{array}$ & $\begin{array}{l}3.67 \pm 0.71 \\
9.02 \pm 3.63\end{array}$ & $\begin{array}{l}3.61 \pm 1.28 \\
7.73 \pm 3.39\end{array}$ & $<0.001$ \\
\hline $\begin{array}{l}\text { T-Chol } \\
\left(\mathrm{mmol}^{-1}\right)\end{array}$ & $\begin{array}{l}\text { Control } \\
\text { Patient }\end{array}$ & $\begin{array}{l}5.13 \pm 1.41 \\
5.17 \pm 1.77\end{array}$ & $\begin{array}{l}5.76 \pm 1.44 \\
4.53 \pm 2.03\end{array}$ & NS \\
\hline $\begin{array}{l}\text { TAG } \\
\left(\mathrm{mmoll}^{-1}\right)\end{array}$ & $\begin{array}{l}\text { Control } \\
\text { Patient }\end{array}$ & $\begin{array}{l}1.88 \pm 0.94 \\
1.79 \pm 1.02\end{array}$ & $\begin{array}{l}1.74 \pm 0.88 \\
2.11 \pm 2.66\end{array}$ & NS \\
\hline Apo $E\left(\mathrm{mg}^{-1}\right)$ & $\begin{array}{l}\text { Control } \\
\text { Patient }\end{array}$ & $\begin{array}{l}47.96 \pm 22.16 \\
40.59 \pm 13.21\end{array}$ & $\begin{array}{l}51.08 \pm 36.72 \\
41.53 \pm 31.31\end{array}$ & $<0.05$ \\
\hline Apo AI $\left(g l^{-1}\right)$ & $\begin{array}{l}\text { Control } \\
\text { Patient }\end{array}$ & $\begin{array}{l}1.37 \pm 0.25 \\
1.42 \pm 0.05\end{array}$ & $\begin{array}{l}1.44 \pm 0.27 \\
1.43 \pm 0.04\end{array}$ & NS \\
\hline Apo B $\left(\mathrm{gl}^{-1}\right)$ & $\begin{array}{l}\text { Control } \\
\text { Patient }\end{array}$ & $\begin{array}{l}1.11 \pm 0.27 \\
1.16 \pm 0.04\end{array}$ & $\begin{array}{l}1.18 \pm 0.32 \\
1.15 \pm 0.05\end{array}$ & NS \\
\hline $\operatorname{Lp}(\mathrm{a})\left(\mathrm{g}^{-1}\right)$ & $\begin{array}{l}\text { Control } \\
\text { Patient }\end{array}$ & $\begin{array}{l}0.16 \pm 0.18 \\
1.16 \pm 2.14\end{array}$ & $\begin{array}{l}0.19 \pm 0.17 \\
1.96 \pm 2.60\end{array}$ & $<0.01$ \\
\hline
\end{tabular}

Values are represented as mean \pm SE. NS, not statistically significant. Total-Cholesterol, T-Chol; triacylglycerol, TAG; apolipoprotein E, Apo E; apolipoprotein AI, Apo AI; apolipoprotein B, Apo B; lipoprotein (a), Lp(a). 
Table 4. Effects of ApoB gene XbaI polymorphism on clinical parameters in non-insulin dependent diabetes mellitus patients and control subjects

\begin{tabular}{|c|c|c|c|c|c|}
\hline & & \multicolumn{3}{|c|}{ Genotype } & \multirow[b]{2}{*}{$p$} \\
\hline & & $\begin{array}{c}\mathrm{X}+/ \mathrm{X}- \\
\text { Control }(n=39) \\
\text { Patient }(n=49)\end{array}$ & $\begin{array}{c}\mathrm{X}-/ \mathrm{X}- \\
\text { Control }(n=47) \\
\text { Patient }(n=48)\end{array}$ & $\begin{array}{c}\mathrm{X}+/ \mathrm{X}+ \\
\text { Control }(n=8) \\
\text { Patient }(n=11)\end{array}$ & \\
\hline \multirow[t]{2}{*}{ BMI $\left(\mathrm{kg} / \mathrm{m}^{-2}\right)$} & Control & $26.90 \pm 3.60$ & $26.91 \pm 4.60$ & $26.28 \pm 3.47$ & \multirow[t]{2}{*}{ NS } \\
\hline & Patient & $26.98 \pm 4.49$ & $27.59 \pm 4.52$ & $28.14 \pm 3.34$ & \\
\hline \multirow[t]{2}{*}{ Glucose $\left(\mathrm{mmoll}^{-1}\right)$} & Control & $3.47 \pm 0.56$ & $3.53 \pm 0.73$ & $4.87 \pm 2.91$ & \multirow[t]{2}{*}{$<0.01$} \\
\hline & Patient & $8.06 \pm 3.67$ & $8.71 \pm 3.51$ & $7.16 \pm 4.31$ & \\
\hline \multirow[t]{2}{*}{ T-Chol $\left(\mathrm{mmoll}^{-1}\right)$} & Control & $5.70 \pm 1.39$ & $5.17 \pm 1.14$ & $6.20 \pm 2.62$ & \multirow[t]{2}{*}{ NS } \\
\hline & Patient & $5.07 \pm 2.02$ & $4.50 \pm 1.80$ & $4.71 \pm 2.16$ & \\
\hline \multirow[t]{2}{*}{ TAG $\left(\mathrm{mmol}^{-1}\right)$} & Control & $1.83 \pm 0.93$ & $1.64 \pm 0.89$ & $1.98 \pm 0.63$ & \multirow[t]{2}{*}{ NS } \\
\hline & Patient & $2.09 \pm 1.69$ & $1.55 \pm 1.01$ & $3.61 \pm 5.37$ & \\
\hline \multirow[t]{2}{*}{ Apo $E\left(m g 1^{-1}\right)$} & Control & $46.31 \pm 17.40$ & $46.38 \pm 19.90$ & $78.16 \pm 82.59$ & \multirow[t]{2}{*}{$<0.05$} \\
\hline & Patient & $42.50 \pm 21.43$ & $36.34 \pm 13.43$ & $57.22 \pm 62.91$ & \\
\hline \multirow[t]{2}{*}{ Apo AI $\left(\mathrm{gl}^{-1}\right)$} & Control & $1.44 \pm 0.24$ & $1.43 \pm 0.27$ & $1.29 \pm 0.30$ & \multirow[t]{2}{*}{ NS } \\
\hline & Patient & $1.44 \pm 0.04$ & $1.39 \pm 0.04$ & $1.46 \pm 0.09$ & \\
\hline \multirow[t]{2}{*}{ Apo B $\left(\mathrm{g}^{-1}\right)$} & Control & $1.22 \pm 0.26$ & $1.05 \pm 0.25$ & $1.24 \pm 0.56$ & \multirow[t]{2}{*}{ NS } \\
\hline & Patient & $1.09 \pm 0.09$ & $1.17 \pm 0.04$ & $1.17 \pm 0.07$ & \\
\hline \multirow[t]{2}{*}{$\operatorname{Lp}(\mathrm{a})\left(\mathrm{gl}^{-1}\right)$} & Control & $0.19 \pm 0.18$ & $0.19 \pm 0.18$ & $0.11 \pm 0.12$ & \multirow[t]{2}{*}{ NS } \\
\hline & Patient & $0.16 \pm 0.03$ & $0.13 \pm 0.02$ & $0.11 \pm 0.02$ & \\
\hline
\end{tabular}

Values are represented as mean \pm SE. NS, not statistically significant. Total-Cholesterol: T-Chol; triacylglycerol, TAG; apolipoprotein E, Apo E; apolipoprotein AI, Apo AI; apolipoprotein B, Apo B; lipoprotein (a), Lp(a).

Table 5. Effects of ApoB gene MspI polymorphism on clinical parameters in non-insulin dependent diabetes mellitus patients and control subjects

\begin{tabular}{|c|c|c|c|c|c|}
\hline & & \multicolumn{3}{|c|}{ Genotype } & \multirow[b]{2}{*}{$p$} \\
\hline & & $\begin{array}{c}\mathrm{M}+/ \mathrm{M}- \\
\text { Control }(n=44) \\
\text { Patient }(n=42)\end{array}$ & $\begin{array}{c}\mathrm{M}-/ \mathrm{M}- \\
\text { Control }(n=26) \\
\text { Patient }(n=26)\end{array}$ & $\begin{array}{c}\mathrm{M}+/ \mathrm{M}+ \\
\text { Control }(n=24) \\
\text { Patient }(n=40)\end{array}$ & \\
\hline \multirow[t]{2}{*}{ BMI $\left(\mathrm{kg} \mathrm{m}^{-2}\right)$} & Control & $27.54 \pm 4.27$ & $25.51 \pm 3.45$ & $27.10 \pm 4.21$ & \multirow[t]{2}{*}{$<0.05$} \\
\hline & Patient & $26.54 \pm 4.81$ & $26.94 \pm 3.67$ & $28.61 \pm 4.09$ & \\
\hline \multirow[t]{2}{*}{ Glucose $\left(\mathrm{mmoll}^{-1}\right)$} & Control & $3.67 \pm 1.41$ & $3.48 \pm 0.72$ & $3.66 \pm 0.59$ & \multirow[t]{2}{*}{$<0.01$} \\
\hline & Patient & $8.49 \pm 3.52$ & $7.32 \pm 2.85$ & $8.57 \pm 4.14$ & \\
\hline \multirow[t]{2}{*}{ T-Chol $\left(\mathrm{mmoll}^{-1}\right)$} & Control & $5.46 \pm 1.30$ & $5.07 \pm 1.29$ & $6.01 \pm 1.68$ & \multirow[t]{2}{*}{$<0.05$} \\
\hline & Patient & $4.84 \pm 2.05$ & $3.30 \pm 1.93$ & $5.51 \pm 1.34$ & \\
\hline \multirow[t]{2}{*}{ TAG $\left(\mathrm{mmoll}^{-1}\right)$} & Control & $1.52 \pm 0.38$ & $1.23 \pm 0.57$ & $2.79 \pm 1.00$ & \multirow[t]{2}{*}{ NS } \\
\hline & Patient & $1.27 \pm 0.29$ & $0.91 \pm 0.19$ & $3.43 \pm 3.13$ & \\
\hline \multirow[t]{2}{*}{ Apo $E\left(m g 1^{-1}\right)$} & Control & $50.07 \pm 41.06$ & $37.32 \pm 11.35$ & $61.64 \pm 15.71$ & \multirow[t]{2}{*}{ NS } \\
\hline & Patient & $37.20 \pm 9.98$ & $28.84 \pm 6.61$ & $53.83 \pm 39.54$ & \\
\hline \multirow[t]{2}{*}{ Apo AI $\left(\mathrm{gl}^{-1}\right)$} & Control & $1.38 \pm 0.22$ & $1.47 \pm 0.31$ & $1.44 \pm 0.27$ & \multirow[t]{2}{*}{ NS } \\
\hline & Patient & $1.42 \pm 0.04$ & $1.38 \pm 0.04$ & $1.45 \pm 0.09$ & \\
\hline \multirow[t]{2}{*}{ Apo B $\left(g 1^{-1}\right)$} & Control & $1.14 \pm 0.30$ & $0.96 \pm 0.25$ & $1.33 \pm 0.23$ & \multirow[t]{2}{*}{ NS } \\
\hline & Patient & $1.07 \pm 0.07$ & $1.14 \pm 0.03$ & $1.15 \pm 0.06$ & \\
\hline \multirow[t]{2}{*}{$\operatorname{Lp}(\mathrm{a})\left(\mathrm{g} 1^{-1}\right)$} & Control & $0.19 \pm 0.18$ & $0.20 \pm 0.18$ & $0.15 \pm 0.17$ & \multirow[t]{2}{*}{ NS } \\
\hline & Patient & $0.14 \pm 0.02$ & $0.11 \pm 0.02$ & $0.10 \pm 0.02$ & \\
\hline
\end{tabular}

Values are represented as mean \pm SE. NS, not statistically significant. Total-Cholesterol: T-Chol; triacylglycerol, TAG; apolipoprotein E, Apo E; apolipoprotein AI, Apo AI; apolipoprotein B, Apo B; Lipoprotein (a), Lp(a).

$\mathrm{XbaI}+/+$ genotypes both for controls and diabetic patients $(p<0.05)$, whereas elevated apo E levels were found in controls with EcoRI $+/+$ genotype. T-Chol levels were found to be higher in MspI $+/+$ genotype carriers in control and diabetic groups $(p<0.05)$. Furthermore, the EcoRI $+/-(p<$ $0.001)$, XbaI $-/-(p<0.001)$, and MspI $+/+$ $(p<0.01)$ genotypes were detected significantly more frequently among type 2 diabetic patients with higher plasma glucose levels. 


\section{DISCUSSION}

Different subsets of genes are probably sufficient to confer susceptibility to type 2 diabetes and susceptibility genes are likely to vary between, and possibly within, populations. Moreover, environmental factors that have still not been fully defined contribute to the development of type 2 diabetes. Thus disease susceptibility genes may be present in unaffected individuals who show a lack of symptoms because they lack the required complement of disease susceptibility genes or necessary environmental factors to induce diabetes. Because of the frequent association of altered cholesterol and TAG metabolism with diabetes, genes that affect lipid metabolism have also been considered as candidate genes for type 2 diabetes. To our knowledge the present study represents the first investigation of the common polymorphisms (EcoRI, XbaI and MspI) of the apo B gene in a Turkish samples with type 2 diabetes and their influence on lipid parameters and disease.

Lipid variation is a usual feature in patients with type 2 diabetes. Several studies have demonstrated an association between variations in the apo B gene and lipoprotein levels which may contribute to the development of type 2 diabetes. The polymorphisms of apo B have been studied more often in coronary artery disease (CAD) by various study groups $27,33-44$ and less frequently in type 2 diabetes. ${ }^{17,18,45,46}$ The allelic variation of apo B gene polymorphisms may have some association with various ethnic groups. The EcoRI $\mathrm{R}+/ \mathrm{R}+$ genotype has been reported to occur most frequently among Koreans, ${ }^{47}$ Japanese, ${ }^{32}$ Caucasions, ${ }^{33}$ and multiethnic Asian populations, ${ }^{10}$ whereas the EcoRI R-/R - genotype has been shown to be the major genotype in Finns ${ }^{34}$ and Caucasions generally. ${ }^{48,49}$ In our study, the $\mathrm{R}+/ \mathrm{R}+$ genotype was found to be the highest in frequency when compared to $\mathrm{R}+/ \mathrm{R}-$ and $\mathrm{R}-/ \mathrm{R}-$ in both patients and controls. The frequency of the XbaI X-allele is high in North Indians, ${ }^{33}$ Koreans ${ }^{47}$ and multiethnic Asian populations. ${ }^{10}$ Ghusn et $a l .{ }^{45}$ and Gutierrez et al. ${ }^{18}$ found no statistically significant difference in the incidence of apo B EcoRI and XbaI alleles respectively among type 2 diabetic patients compared to controls. While Houlston et al. ${ }^{9}$ found the E- allele over-represented in type 2 diabetic patients when compared to controls. In our study, we found the $\mathrm{XbaI} \mathrm{X}+/ \mathrm{X}-$ genotype frequency to be highest among diabetics, whereas the $\mathrm{X}-/ \mathrm{X}-$ genotpe had the highest frequency in the controls. In the present study, no significant differences were observed in genotype frequencies at the EcoRI, $\mathrm{XbaI}$ and MspI polymorphic sites in the apo B gene between type 2 diabetic patients and controls.

Apo B polymorphisms in type 2 diabetes have been studied in a number of populations, and data showing the effect of EcoRI polymorphism on cholesterol levels differ among these ethnic groups. Ukkola et $a{ }^{46}{ }^{46}$ have reported higher plasma cholesterol and TAG concentrations in type 2 diabetic patients with the $\mathrm{X}+\mathrm{X}+$ genotype, whereas Houlston et al. ${ }^{9}$ and Gutierrez et al. ${ }^{18}$ did not find any significant relationship between XbaI polymorphism and serum lipids in patients with type 2 diabetes. The apo B gene EcoRI E-/E - genotype was found to be correlated with higher TAG levels in type 2 diabetic patients. ${ }^{9}$ Hypercholesterolemic patients with EcoRI $\mathrm{R}+/ \mathrm{R}+$ (presence of the cutting site) are known to have lower T-Chol, VLDL-Chol, LDL-Chol and slower fractional catabolic rate (FCR) for LDL, and their VLDL is richer in cholesterol than that of patients with EcoRI $\mathrm{R}+/ \mathrm{R}-$. Thus, hypercholesterolemia can be due to particle-related slow clearance of LDL in some patients. ${ }^{36}$ Thus, results concerning the role of apo B polymorphisms in lipid metabolism are contradictory, and depend on the particular population. In the present study we were not able to show a clear significant association of the EcoRI polymorphism in the apo B gene with variation in T-Chol, whereas a significant association was observed for apo E and $L p(a)$ levels in the $\mathrm{R}+/ \mathrm{R}+$ genotype of type 2 diabetic patients who had higher levels of apo E and $L p(a)$ in comparison to the $\mathrm{R}+/ \mathrm{R}-$ genotype. On the other hand, the $\mathrm{R}+/ \mathrm{R}$ - genotype of the EcoRI site was significantly associated with higher levels of plasma glucose as compared to the $\mathrm{R}+/ \mathrm{R}+$ genotype. In our study, although the lipid variables were lower in the $\mathrm{X}-/ \mathrm{X}$ - genotype when compared to $\mathrm{X}+/ \mathrm{X}-$ and $\mathrm{X}+\mathrm{X}+$, the difference did not reach significance either in the type 2 diabetic or in the control group except for apo E. The apo E levels were found to be significantly higher in $\mathrm{X}+/ \mathrm{X}+$ for both groups when compared to the $\mathrm{X}-/ \mathrm{X}-$ and $\mathrm{X}+/ \mathrm{X}-$ genotypes. The MspI polymorphism has not been found to be associated with differences in serum lipid concentrations. ${ }^{41,48-51}$

An explanation for the differences in allele frequency and lipid association of the apo B polymorphisms among the populations studied, is that in the genetic background there may be a more important factor than environmental variation, such as diet or lifestyle. Another possibility is that this may be the result of differences in linkage disequilibria between the different polymorphic sites of the apo B gene in the different populations. 
In conclusion, there was no significant difference in genotypic frequencies of the EcoRI, XbaI and MspI sites of the apo B gene between the patient and control groups, and the presence of the EcoRI and XbaI cutting site of the apo B gene is associated with higher serum apo E levels, whereas the presence of the MspI restriction site is associated with higher T-Chol levels in this sample of Turkish type 2 diabetic patients. The EcoRI, XbaI and MspI genotypes were found to be associated with plasma glucose levels.

\section{ACKNOWLEDGEMENTS}

This work was supported by the Research Fund of the University of Istanbul, project number, 1509/ 28072000 .

\section{REFERENCES}

1. Report of the expert committee on the diagnosis and classification of diabetes mellitus. Diabetes Care 1997; 20: 1183-1197.

2. Gonzelez C, Stern MP, Mitchell BD, Valdez RA, Haffner SM, Perez BA. Clinical characteristics of type II diabetic subjects consuming high versus low carbohydrate diets in Mexico City and San Antonio, Texas. Diabetes Care 1994; 17: 397404.

3. Poulsen P, Vaag A, Kyvik K, Beck-Nielsen H. Genetic versus environmental aetiology of the metabolic syndrome among male and female twins. Diabetologia 2001; 44: 537-543.

4. Kahn CR. Banting Lecture. Insulin action, diabetogenes, and the cause of type II diabetes. Diabetes 1994; 43: 1066-1084.

5. Matsumoto K, Sakamaki H, Izumino K, et al. Increased insulin sensitivity and decreased insulin secretion in offspring of insulin-sensitive type 2 diabetic patients. Metabolism 2001; 49: 1219-1223.

6. Morton NE, Lio P. Oligogenic linkage and map integration. In Genetic Mapping of Disease Genes (1st edn), Pawlowitzki H, Edwards JH, Thompson EA (eds). Academic Press: San Diego, CA, 1997; 17-21.

7. De Meyts P. The diabetogenes concept of NIDDM. Adv Exp Med Biol 1993; 334: 89-100.

8. Brown MS, Goldstein JL. A receptor-mediated pathway for cholesterol homeostasis. Science 1986; 232: 34-47.

9. Houlston RS, Snowden C, Laker MF, Alberti KG, Humphries SE. Variation in the apolipoprotein B gene and development of type 2 diabetes mellitus. Dis Markers 1991; 9: 87-96.

10. Choong ML, Sethi SK, Koay ES. Effects of intragenic variability at 3 polymorphic sites of the apolipoprotein B gene on serum lipids and lipoproteins in a multiethnic Asian population. Hum Biol 1999; 71: 381-397.

11. Haffner SM. Management of dyslipidemia in adults with diabetes. Diabetes Care 1998; 21: 160-178.

12. Taskinen MR. Hyperlipidaemia in diabetes. Baillieres Clin Endocrinol Metab 1990; 4: 743-775.

13. Kannel WB. Lipids, diabetes, and coronary heart disease: insights from the Framingham Study. Am Heart J 1985; 110: 1100-1107.

14. Caixas A, Ordonez-Llanos J, de Leiva A, Payes A, Homs R, Perez A. Optimization of glycemic control by insulin therapy decreases the proportion of small dense LDL particles in diabetic patients. Diabetes 1997; 46: 1207-1213.

15. Brown MS, Goldstein JL. How LDL receptors influence cholesterol and atherosclerosis. Sci Am 1984; 251: 58-66.

16. Knott TJ, Rall SC, Innerarity TL, et al. Human apolipoprotein B: structure of carboxyl-terminal domains, sites of gene expression, and chromosomal localization. Science 1985; 230: $37-43$.

17. Xiang KS, Cox NJ, Sanz N, Huang P, Karam JH, Bell GI. Insulin-receptor and apolipoprotein genes contribute to development of NIDDM in Chinese Americans. Diabetes 1989; 38 : $17-23$.

18. Gutierrez C, Vendrell J, Broch M, et al. Apolipoprotein AI-CIII, $\mathrm{B}$, and CII gene polymorphisms in patients with non-insulin dependent diabetes mellitus. Association with hyperlipemia. Med Clin (Barc) 1996; 107: 561-565.

19. Berg K, Hames C, Dahlen G, Frick MH, Krishan I. Genetic variation in serum low density lipoproteins and lipid levels in man. Proc Natl Acad Sci USA 1976; 73: 937-940.

20. Ma YH, Schumaker VN, Butler R, Sparkes RS. Two DNA restriction fragment length polymorphisms associated with $\operatorname{Ag}(\mathrm{t} / \mathrm{z})$ and $\operatorname{Ag}(\mathrm{g} / \mathrm{c})$ antigenic sites of human apolipoprotein B. Arteriosclerosis 1987; 7: 301-305.

21. Huang LS, de Graaf J, Breslow JL. ApoB gene MspI RFLP in exon 26 changes amino acid 3611 from Arg to Gln. J Lipid Res 1988; 29: 63-67.

22. Peacock R, Dunning A, Hamsten A, Tornvall P, Humphries S, Talmud P. Apolipoprotein B gene polymorphisms, lipoproteins and coronary atherosclerosis: a study of young myocardial infarction survivors and healthy population-based individuals. Atherosclerosis 1992; 92: 151-164.

23. Renges HH, Peacock R, Dunning AM, Talmud P, Humphries SE. Genetic relationship between the $3^{\prime}$-VNTR and diallelic apolipoprotein B gene polymorphisms: haplotype analysis in individuals of European and south Asian origin. Ann Hum Genet 1992; 56: 11-33.

24. Law A, Wallis SC, Powell LM, et al. Common DNA polymorphism within coding sequence of apolipoprotein $\mathrm{B}$ gene associated with altered lipid levels. Lancet 1986; 1: 1301-1303.

25. Talmud PJ, Barni N, Kessling AM, et al. Apolipoprotein B gene variants are involved in the determination of serum cholesterol levels: a study in normo- and hyperlipidaemic individuals. Atherosclerosis 1987; 67: 81-89.

26. Berg K. DNA polymorphism at the apolipoprotein B locus is associated with lipoprotein level. Clin Genet 1986; 30: 515520.

27. Gylling H, Kontula K, Koivisto UM, Miettinen HE, Miettinen TA. Polymorphisms of the genes encoding apoproteins A-I, B, $\mathrm{C}$-III, and E and LDL receptor, and cholesterol and LDL metabolism during increased cholesterol intake. Common alleles of the apoprotein $\mathrm{E}$ gene show the greatest regulatory impact. Arterioscler Thromb Vasc Biol 1997; 17: 38-44.

28. World Health Organization. Definition, Diagnosis and Classification of Diabetes Mellitus and its Complications. World Health Organization: Geneva, 1999.

29. Arroyo P, Pardio J, Fernandez V, Vargas-Ancona L, Canul G, Loria A. Obesity and cultural environment in the Yucatan region. Nutr Rev 1999; 57: S78-S82.

30. Miller SA, Dykes DD, Polesky HF. A simple salting out procedure for extracting DNA from nucleated cells. Nucleic Acids Res 1988; 16: 1215.

31. Saiki RK, Gelfand DH, Stoffel S, et al. Primer-directed enzymatic amplification of DNA with a thermostable DNA polymerase. Science 1988; 239: 487-491. 
32. Iso $\mathrm{H}$, Harada $\mathrm{S}$, Shimamoto $\mathrm{T}$, et al. Polymorphism of the apolipoprotein B gene and blood lipid concentrations in Japanese and Caucasian population samples. Atherosclerosis 1996; 126: 233-241.

33. Misra A, Nishanth S, Pasha ST, Pandey RM, Sethi P, Rawat DS. Relationship of Xba1 and EcoR1 polymorphisms of apolipoprotein-B gene to dyslipidemia and obesity in Asian Indians in North India. Indian Heart J 2001; 53: 177-183.

34. Horvath A, Chorbov V, Zaharova B, Ganev V. Five polymorphisms of the apolipoprotein B gene in healthy Bulgarians. Hum Biol 2003; 75: 69-80.

35. Chan L, Dresel H. Genetic factors influencing lipoprotein structure: implications for atherosclerosis. Lab Invest 1990; 62: $522-537$.

36. Korhonen T, Savolainen MJ, Kesaniemi YA. Variation of apolipoprotein B as a possible cause of decreased low density lipoprotein clearance and hypercholesterolemia. Atherosclerosis 1999; 146: 1-10.

37. Delghandi M, Thangarajah R, Nilsen M, et al. 1999. DNA polymorphisms of the apolipoprotein B gene (XbaI, EcoRI, and MspI RFLPs) in Norwegians at risk of atherosclerosis and healthy controls. Acta Cardiol 1999; 54: 215-225.

38. Guzman EC, Hirata MH, Quintao EC, Hirata RD. Association of the apolipoprotein B gene polymorphisms with cholesterol levels and response to fluvastatin in Brazilian individuals with high risk for coronary heart disease. Clin Chem Lab Med 2000; 38: 731-736.

39. Machado MO, Hirata MH, Bertolami MC, Hirata RD. Apo B gene haplotype is associated with lipid profile of higher risk for coronary heart disease in Caucasian Brazilian men. J Clin Lab Anal 2001; 15: 19-24.

40. West KM, Ahuja MM, Bennett PH, et al. The role of circulating glucose and triglyceride concentrations and their interactions with other 'risk factors' as determinants of arterial disease in nine diabetic population samples from the WHO multinational study. Diabetes Care 1983; 6: 361-369.

41. Genest JJ Jr, Ordovas JM, McNamara JR, et al. DNA polymorphisms of the apolipoprotein B gene in patients with premature coronary artery disease. Atherosclerosis 1990; 82: $7-17$.

42. Siest G, Henny J, Galteau MM, Schiele F, Steinmetz J, Visvikis S. Lipid and lipoprotein genetic variability: an important contribution from the French health examination centers. Clin Biochem 1995; 28: 31-38.

43. Howard BV, Lee ET, Fabsitz RR, et al. Diabetes and coronary heart disease in American Indians: the Strong Heart Study. Diabetes 1996; 45(Suppl. 3): S6-S13.

44. Puri RD, Tewari S, Sinha N, et al. Polymorphisms in the apolipoprotein B-100 gene: association with plasma lipid concentration and coronary artery disease. Indian Heart $J$ 2003; 55: 60-64.

45. Ghusn H, Arem R, Frazier M, Chamakhi S, Ezzaouia G, Chan L. Restriction fragment length polymorphism of the human apo $\mathrm{B}$ and apo AII gene regions among type II diabetics. Res Commun Mol Pathol Pharmacol 1996; 93: 25-32.

46. Ukkola O, Savolainen MJ, Salmela PI, von Dickhoff K, Kesaniemi YA. Apolipoprotein B gene DNA polymorphisms are associated with macro- and microangiopathy in non-insulindependent diabetes mellitus. Clin Genet 1993; 44: 177-184.

47. Hong SH, Song J, Kim JQ. The haplotype analyses using multiple markers of the apolipoprotein B gene in patients with coronary artery disease. J Korean Med Sci 2001; 16: 719-724.

48. Hegele RA, Huang LS, Herbert PN, et al. Apolipoprotein Bgene DNA polymorphisms associated with myocardial infarction. N Engl J Med 1986; 315: 1509-1515.

49. Tybjaerg-Hansen A, Nordestgaard BG, Gerdes LU, Humphries SE. Variation of apolipoprotein B gene is associated with myocardial infarction and lipoprotein levels in Danes. Atherosclerosis 1991; 89: 69-81.

50. Deeb S, Failor A, Brown BG, Brunzell JD, Albers JJ, Motulsky AG. Molecular genetics of apolipoproteins and coronary heart disease. Cold Spring Harb Symp Quant Biol 1986; 51: 403-409.

51. Xu CF, Nanjee N, Tikkanen MJ, et al. Apolipoprotein B amino acid 3611 substitution from arginine to glutamine creates the $\mathrm{Ag}$ (h/i) epitope: the polymorphism is not associated with differences in serum cholesterol and apolipoprotein B levels. Hum Genet 1989; 82: 322-326. 